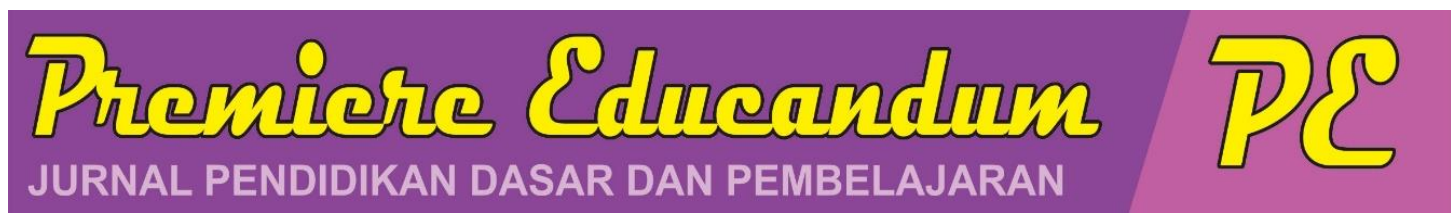

Premiere Educandum: Jurnal Pendidikan Dasar dan Pembelajaran

Volume 9 (2) 91 - 99 Desember 2019

Copyright @2019 Universitas PGRI Madiun

ISSN: 2088-5350 (Print) / ISSN: 2528-5173 (Online)

Available at: http://e-journal.unipma.ac.id/index.php/PE

Doi: 10.25273 /pe.v9i2.4470

\title{
Peningkatan sikap ilmiah dan prestasi belajar menggunakan model Science, Technology, Engineering, and Mathematics di kelas V MIM kramat
}

\author{
Nina Veronica Septine ${ }^{1}$, Okto Wijayanti ${ }^{2}$, dan Badarudin ${ }^{3}$. \\ ${ }^{1,2,3}$ FKIP, PGSD, Universitas Muhammadiyah Purwokerto \\ 1email: 1501100271@ump.ac.id \\ 2email: oktowijayanti@ump.ac.id \\ 3email: badarudin@ump.ac.id
}

\begin{abstract}
The background in this study is the low scientific attitude and learning achievement of students. This study discusses improving scientific attitudes and learning achievement of students using learning models Science, Technology, Engineering, and Mathematic (STEM). This type of research is classroom action research model Kemmis and Mc. Taggart. The stage in this study consists of 4 stages, namely the planning stage, the action stage, the observation stage, and the reflection stage. The implementation of the study was conducted in 2 cycles, where each cycle consisted of 2 meetings. The research subjects were class V MI Muhammadiyah Kramat Academic Year 2018/2019, totaling 20 students. The results of the study have increased in each cycle. The researcher found findings that the higher the scientific attitude possessed by students, the higher the learning achievement achieved by students. The results and discussion in this study show that the learning model of Science, Technology, Engineering, and Mathematic (STEM) can improve the scientific attitude and learning achievement of students in theme 8 in the fifth grade of MI Muhammadiyah Kramat, Kembaran District, Banyumas Regency, Central Java
\end{abstract}

Keywords: Scientific Attitude, Learning Achievement, STEM

\begin{abstract}
Abstrak
Latarbelakang dalam penelitian ini adalah rendahnya sikap ilmiah dan prestasi belajar peserta didik. Penelitian ini membahas peningkatan sikap ilmiah dan prestasi belajar peserta didik menggunakan model pembelajaran Science, Technology, Engineering, and Mathematic (STEM). Jenis penelitian adalah penelitian tindakan kelas model Kemmis and Mc. Taggart. Tahap dalam penelitian ini terdiri dari 4 tahapan yakni tahap perencanaan, tahap tindakan, tahap observasi, dan tahap refleksi. Pelaksanaan penelitian dilakukan sebanyak 2 siklus, dimana setiap siklusnya terdiri dari 2 pertemuan. Subjek penelitian yakni peserta didik kelas V MI Muhammdiyah Kramat Tahun Ajaran 2018/2019, yang berjumlah 20 peserta didik. Hasil penelitian mengalami peningkatan setiap siklus. Peneliti menemukan temuan bahwa semakin tinggi sikap ilmiah yang dimiliki oleh peserta didik maka semakin tinggi juga prestasi belajar yang dicapai oleh peserta didik. Hasil dan pembahasan pada penelitian ini menunjukan bahwa model pembelajaran Science, Technology, Engineering, and Mathematic (STEM) dapat meningkatkan sikap ilmiah dan prestasi belajar peserta didik pada tema 8 di kelas V MI Muhammadiyah Kramat, Kecamatan Kembaran, Kabupaten Banyumas, Jawa Tengah.
\end{abstract}

Kata Kunci: Sikap Ilmiah, Prestasi Belajar, STEM

Histori artikel : disubmit pada 17 Juni 2019; direvisi pada 26 Juli 2019; diterima pada 05 Juli 2019 


\section{A. PENDAHULUAN}

Pembelajaran merupakan interaksi antara pendidik dan peserta didik, dimana pendidik menyalurkan materi yang ia miliki kepada peserta didik. Mc Mahon (Trianto, 2012) mengatakan bahwa belajar bukanlah semata mata mentransfer pengetahuan yang ada di luar dirinya, tetapi belajar lebih bagaimana otak memproses dan menginterpretasikan pengalaman yang baru dengan pengetahuan yang sudah dimilikinya dalam format yang baru.

Pemerintah saat ini pada tahun 2019 sudah menerapkan Kurikulum 2013 atau Kurtilas untuk semua sekolah khususnya SD/MI. Kurikulum 13 merupakan kurikulum yang mengintegrasikan beberapa mata pelajaran ke dalam tema, sehingga membuat peserta didik lebih aktif dan memberikan gambaran yang lebih konkret dari sebuah ilmu, karena materi yang diajarkan tidak hanya saling keterkaitan antara mata pelajaran, namun juga dikaitkan dengan peristiwa alam atau kejadian sehari-hari yang ada di sekitar kehidupan manusia. Salah satu kendala dari kurikulum 2013 yakni metode atau model yang digunakan untuk menyampaikan materi pembelajaran yang ingin diajarkan belum efektif atau bahkan tidak sesuai dengan materi yang ingin disampaikan (Kurniaman \& Noviana, 2019).

Berdasarkan hasil observasi yang dilakukan di MI Muhammadiyah Kramat diperoleh data awal sebagian peserta didik kurang memiliki rasa ingin tahu bagaimana sesuatu dapat terjadi, sebagian peserta didik kurang memiliki rasa menghargai teman, hal tersebut tampak ketika ada peserta didik yang sedang menyampaikan hasil diskusi, pada saat proses pembelajaran berlangsung masih ditemukan peserta didik yang cenderung mengobrol sengan teman sebangkunya dan tidak memperhatikan. Hasil pengamatan juga menunjukan peserta didik kurang memiliki rasa pantang menyerah, hal tersebut tampak ketika peserta didik merasa kesulitan mengerjakan soal atau pertayaan mereka akan mengatakan kepada Guru bahwa soal atau pertanyaan yang mereka dapatkan sulit dikerjakan kemudian peserta didik memilih tidak mengerjakan pertanyaan sulit.

Beberapa permasalahan diatas dapat dikategorikan sebagai sikap ilmiah yang masih rendah, antara lain yaitu sikap ingin tahu, sikap menghargai, sikap pantang menyerah, yang belum dimiliki oleh peserta didik kelas V MIM Kramat. Permasalahan rendahnya sikap ilmiah yang dimiliki peserta didik maka berimbas pada hasil prestasi belajar peserta didik juga rendah. Prestasi belajar yang rendah tampak pada hasil Penilaian Akhir Semester 1 Kelas V MI Muhammadyah Kramat Tahun Ajaran 2018/2019.

Hasil observasi dan analisis tersebut melengkapi juga hasil penelitian yang dilakukan oleh (Hunaepi, 2016) bahwa sikap ilmiah sangat menentukan keberhasilan seseorang peserta didik untuk mencapai ketuntasan dalam proses pembelajaran. Ketika sikap ilmiah rendah maka akan berimbas pada prestasi belajar peserta didik. Guru perlu meningkatkan sikap ilmiah peserta didik terlebih dahulu, sehingga 
ketika sikap ilmiah peserta didik meningkat maka prestasi belajar peserta didik akan meningkat. Hal serupa juga disampaikan oleh (Suryani, 2016) dalam penelitiannya menyampaikan bahwa sikap ilmiah dan prestasi belajar memiliki hubungan yang positif. Semakin positif sikap ilmiah yang dimiliki peserta didik maka semakin tinggi prestasi belajar peserta didik.

Pembelajaran bukan hanya merupakan penguasaan kumpulan pengetahuan yang berupa fakta-fakta, konsep-konsep atau prinsip saja, tetapi juga proses penemuan dan pembentukan sikap ilmiah (Sardinah, Tursinawati, \& Noviyanti, 2012). Selain pemaparan dari hasil observasi tersebut, guru juga mengatakan bahwa belum menemukan model pembelajaran yang sesuai untuk diterapkan di kelas V MI Muhammadiyah Kramat. Guru membutuhkan model pembelajaran yang mampu meningkatkan sikap ilmiah peserta didik, sehingga juga dapat meningkatkan prestasi belajar peserta didik.

Penelitian terdahulu yang dilakukan oleh (El-Deghaidy \& Mansour, 2015) mengutarakan bahwa dalam menghadirkan pembelajaran konten pengetahuan pendadogis Guru perlu untuk memberlakukan pendidikan STEM di kelas. Pada penelitian tindakan kelas ini peneliti tidak hanya menghadirkan pembelajaran STEM di dalam kelas, peneliti juga akan menghadirkan pembelajaran STEM saat diluar kelas. Ketika pembelajaran STEM berlangsung diluar kelas, peserta didik akan berinteraksi dengan objek pembelajaran dan akan lebih banyak mengamati, sehingga dapat meningkatkan sikap ilmiah peserta didik.

Model pembelajaran Science, Technology, Engineering, and Mathematics (STEM) merupakan pembelajaran menggunakan pendekatan dari ke empat aspek yang saling dikaitkan dengan dunia nyata, memberikan kesempatan kepada peserta didik untuk menghubungkan pengetahuan yang di dapat dari kehidupan sehari-hari. STEM mampu meningkatkan

penguasaan pengetahuan, mengaplikasikan pengetahuan untuk memecahkan masalah, serta mendorong peserta didik untuk mencipta sesuatu yang baru (Permanasari, 2016).

Berdasarkan permasalahan tersebut peneliti tertarik untuk melakukan penelitian tindakan kelas tentang upaya meningkatakan sikap ilmiah dan prestasi belajar peserta didik kelas $\mathrm{V}$ menggunakan model pembelajaran Science, Technology, Engineering, and Mathematics (STEM) pada Tema 8 di MI Muhammadiyah Kramat. Tujuan penelitian ini adalah untuk mengetahui peningkatan sikap ilmiah dan prestasi belajar peserta didik.

\section{B. METODE PENELITIAN}

Penelitian ini merupakan Penelitian Tindakan Kelas model Kemmis dan Mc Taggart. PTK model Kemmis dan Mc Taggart terdiri dari 4 tahapan, yaitu tahap perencanaan, tahap tindakan, tahap observasi, dan tahap refleksi. Penelitian dilaksanakan dalam 2 siklus, setiap siklusnya dilakukan 2 kali pertemuan. Penelitian 
dilaksanakan di MI Muhammadiyah Kramat, pada bulan Maret-April 2019. Subjek penelitian ini adalah peserta didik Kelas V MI Muhammadiyah Kramat Tahun Ajaran 2018/2019 berjumlah 20 peserta didik, yang terdiri dari 15 peserta didik putra dan 5 peserta didik putri.

Teknik pengumpulan data yang digunakan dalam penelitian ini adalah tes dan non tes. Alat pengumpul data tes berupa lembar evaluasi. Lembar evaluasi yang diberikan diakhir siklus digunakan untuk mengukur sejauh mana penguasaan materi yang dimiliki peserta didik. Alat pengumpul data non tes berupa lembar observasi sikap ilmiah, lembar angket skala sikap. Lembar observasi sikap ilmiah digunakan untuk mengamati perkembangan sikap ilmiah yang dimiliki peserta didik, sedangkan lembar angket skala sikap bertujuan untuk mengetahui respon peserta didik terhadap sesuatu, hasil lembar angket skala sikap digunakan untuk mengukur sikap ilmiah yang dimiliki peserta didik.

Setelah mendapatkan data penelitian kemudian peneliti mengalisis data yang telah didapatkan. Analisis data yang digunakan yakni, analisis prestasi belajar, digunakan untuk menganalisis hasil dari lembar evaluasi apakah mencapai KKM dan ketuntasan belajar yang diharapkan, yakni sebanyak $80 \%$. Selain itu ada analisis lembar observasi sikap ilmiah, dan analisis lembar angket sikap ilmiah, yang bertujuan untuk mengetahui seberapa tingkat sikap ilmiah yang dimiliki oleh peserta didik.
Indikator keberhasilan pada penelitian tindakan kelas yang dilakukan yakni: 1) Peningkatan sikap ilmiah peserta didik dengan penerapan model Science, Technology, Engineering, and Mathematics (STEM), sekurang-kurangnya sikap ilmiah peserta didik mencapai 3,4 < M $\leq 4,2$ yang termasuk dalam kategori sikap ilmiah peserta didik baik. 2) Peningkatan prestasi belajar peserta didik dengan penerapan model Science, Technology, Engineering, and Mathematics (STEM), sekurangkurangnya prestasi belajar peserta didik mencapai KKM yang telah di tentukan sekolah yakni 70 dan ketuntasan belajar mencapai sekurangkurangnya $80 \%$.

\section{HASIL DAN PEMBAHASAN Hasil}

Hasil analisis dari lembar observasi sikap ilmiah peserta didik mengalami peningkatan yang dapat dilihat pada tabel 1.1 berikut ini:

Tabel 1.1 Rekapitulasi Lembar Observasi Sikap Ilmiah Peserta Didik.

\begin{tabular}{clcc}
\hline \multirow{2}{*}{ No } & \multirow{2}{*}{ Pencapaian } & \multicolumn{2}{c}{ Siklus } \\
\cline { 3 - 4 } 1 & $\begin{array}{l}\text { Persentase Per } \\
\text { Siklus }\end{array}$ & $50.35 \%$ & $77.5 \%$ \\
\hline 2 & $\begin{array}{l}\text { Kriteria Per } \\
\text { Siklus }\end{array}$ & Kurang & Baik \\
\hline
\end{tabular}

Berdasarkan tabel 1.1 dapat diketahui peningkatan siklus I ke siklus II terjadi sebesar $27.15 \%$. Peneliti menemukan temuan saat pembelajaran guru mengaitkan materi dengan contoh kehidupan peserta didik. Guru mengaitkan materi air tanah dengan proses penyerapan air pada batu bata. Peserta didik sangat antusias karena contoh yang diberikan guru berada disekitar kehidupan peserta didik, sehingga lebih mudah 
memahami materi. Peningkatan sikap ilmiah juga tampak pada hasil analisis lembar angket sikap ilmiah yang dapat dilihat pada tabel 1.2 berikut ini:

Tabel 1.2 Rekapitulasi Lembar Angket Sikap Ilmiah Peserta Didik.

\begin{tabular}{cccc}
\hline \multirow{2}{*}{ No } & \multirow{2}{*}{ Pencapaian } & \multicolumn{2}{c}{ Siklus } \\
\cline { 3 - 4 } & & I & II \\
\hline $\mathbf{1}$ & Rata-rata Skor & 3.7 & 4.2 \\
\hline $\mathbf{2}$ & Kriteria & Baik & Baik \\
\hline
\end{tabular}

Data yang diperoleh dari tabel 1.2 diketahui terdapat peningkatan rata-rata skor sebesar 0.5 dari siklus I ke siklus II. Saat kerja kelompok air tanah, peserta didik berdiskusi dan bertukar pikiran mengapa batu bata dapat menyerap air dan batu tidak dapat, hal tersebut membuat peserta didik yang belum tahu menjadi tahu. Secara tidak langsung pada siklus II sudah muncul sikap ilmiah pada peserta didik. Berikut ini merupakan tabel 1.3 hasil analisis prestasi belajar untuk mata pelajaran B.Indonesia:

Tabel 1.3 Peningkatan Prestasi Belajar Mata Pelajaran Bahasa Indonesia.

\begin{tabular}{clcc}
\hline No & Indikator & $\begin{array}{c}\text { Siklus } \\
\text { I }\end{array}$ & $\begin{array}{c}\text { Siklus } \\
\text { II }\end{array}$ \\
\hline $\mathbf{1}$ & $\begin{array}{l}\text { Rata-rata } \\
\text { Nilai }\end{array}$ & 55.05 & 74.48 \\
\hline $\mathbf{2}$ & $\begin{array}{l}\text { Ketuntasan } \\
\text { Belajar }\end{array}$ & $35.3 \%$ & $84.5 \%$ \\
\hline
\end{tabular}

Rata-rata Nilai B.Indonesia dari siklus I ke siklus II mengalami peningkatan sebesar 19,43. Ketuntasan belajar peserta didik mengalami peningkatan sebesar 49,2\%. Berikut merupakan tabel hasil analisis peningkatan prestasi belajar mata pelajaran IPA:

Tabel 1.4 Peningkatan Prestasi Belajar Mata Pelajaran IPA.

\begin{tabular}{clcc}
\hline No & \multicolumn{1}{c}{ Indikator } & $\begin{array}{c}\text { Siklus } \\
\text { I }\end{array}$ & $\begin{array}{c}\text { Siklus } \\
\text { II }\end{array}$ \\
\hline $\mathbf{1}$ & Rata-rata Nilai & 55.1 & 71.65 \\
\hline $\mathbf{2}$ & $\begin{array}{l}\text { Ketuntasan } \\
\text { Belajar }\end{array}$ & $40.3 \%$ & $82 \%$ \\
\hline
\end{tabular}

Rata-rata Nilai IPA dari siklus I ke siklus II mengalami peningkatan sebesar 16,55. Ketuntasan belajar peserta didik mengalami peningkatan sebesar $41,7 \%$. Peningkatan prestasi belajar yang terjadi pada siklus I dan siklus II tersebut terjadi secara berkala dan berkesinambungan. Peningkatan yang terjadi

\section{Pembahasan}

Penggunaan model pembelajaran Science, Technology, Engineering, and Mathematics (STEM) kelas V MI Muhammadiyah Kramat Tema 8 lebih di fokuskan pada mata pelajaran Bahasa Indonesia dan IPA. Saat awal penelitian dilaksanakan guru dan peserta didik masih beradaptasi dengan pembelajaran model STEM, namun pada penelitian di pertemuan berikutnya guru sudah lebih memahami langkah dari model pembelajaran STEM. Histogram peningkatan sikap ilmiah dari lembar observasi sikap ilmiah dapat dilihat pada gambar 1.1 berikut ini:

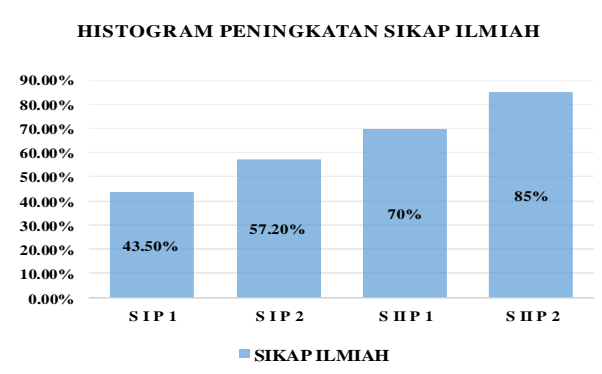

Gambar 1.1 Histogram Peningkatan Sikap Ilmiah dari Lembar Observasi Sikap Ilmiah.

Ketika observasi di siklus II peneliti menemukan temuan, yakni saat peserta didik maju menyampaikan hasil diskusi tentang air tanah dan air permukaan peserta didik yang lain sudah dapat tenang dan menghargai yang menyajikan hasil diskusi. Selain itu ketika praktikum pembuatan penyaringan air sederhana, peserta didik sudah dapat berdiskusi dan 
bekerja sama, kemajuan tersebut tidak terlepas dari peran guru kelas. Temuan tersebut sesuai dengan pendapat yang mengatakan bahwa di negara Indonesia sikap ilmiah yang harus lebih dahulu dilatihkan adalah kemampuan untuk menghargai orang lain dan keberanian siswa untuk menjawab pertanyaan, mengajukan pertanyaan, dan diskusi, untuk mengembangkan perilaku tersebut diperlukan aturan dan motivasi dari guru di kelas (Alawiyah, Sopandi, \& Indonesia, 2006).

Peningkatan sikap ilmiah peserta didik tidak hanya terlihat dari hasil analisis lembar observasi sikap ilmiah, namun juga terlihat pada hasil analisis lembar angket sikap ilmiah. Histogram peningkatan sikap ilmiah dari lembar angket sikap ilmiah dapat dilihat pada gambar 1.2 berikut ini:

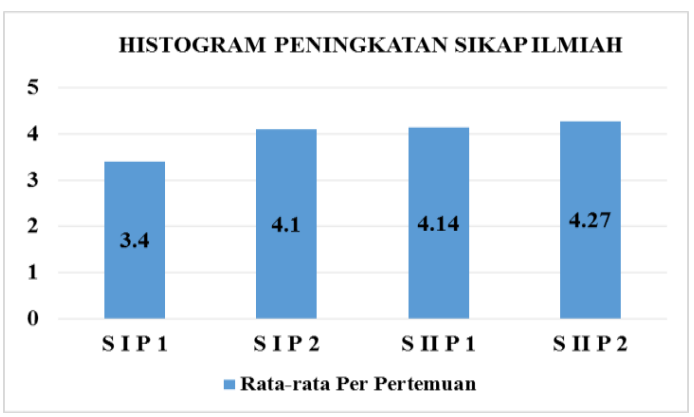

Gambar 1.2 Histogram Peningkatan Sikap Ilmiah dari Lembar Angket Sikap Ilmiah.

Peningkatan sikap ilmiah tampak saat kerja kelompok pembuatan penyaring air sederhana, guru menghadirkan permasalahan terkait ketersediaan air bersih yang semakin menipis, kemudian peserta didik saling berdiskusi untuk menemukan dan mengembangkan solusi pemecahan masalah ketersediaan air bersih yang semakin menipis. Temuan tersebut sesuai dengan pendapat yang mengungkapkan bahwa karakteristik STEM lebih menekankan pada proses mendesain, design proses adalah pendekatan sistematis dalam mengembangkan solusi dari masalah
(Jauhariyyah, Hadi Suwono, \& Ibrohim, 2017). Selain peningkatan sikap ilmiah pada peserta didik kelas V MI Muhammadiyah Kramat, prestasi belajar peserta didik juga mengalami peningkatan. Peningkatan prestasi belajar peserta didik tampak pada gambar 1.3 berikut ini:

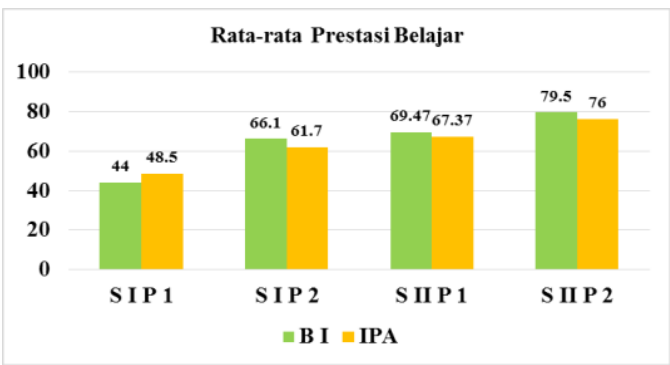

Gambar 1.3 Histogram Peningkatan Prestasi Belajar Peserta Didik.

Peneliti menemukan temuan bahwa guru melakukan pengaitan materi yang satu dengan materi pelajaran lainnya dalam satu pembelajaran, dengan cara tersebut membuat peserta didik lebih dapat berfikir bebas. Ketika guru menyampaikan materi tentang pokok pikiran dari bacaan teks Warga Desawaborobo Sulit mendapatkan Air, saat itu juga guru mulai memasuki materi manfaat air. Perpaduan antara mata pelajaran Bahasa Indonesia dan IPA membuat peserta didik mendapatkan gambaran nyata sebuah materi/ilmu.

Peningkatan tersebut juga tampak saat guru mengajar menggunakan model pembelajaran Science, Technology, Engineering, and Mathematics (STEM) yang menggabungkan mata pelajaran Bahasa Indonesia dan IPA, temuan tersebut sesuai dengan pendapat Ismayani (Utami, Jatmiko, \& Suherman, 2018) yang mengatakan bahwa Science, Technology, Engineering, and Mathematics (STEM) merupakan pembelajaran yang menggabungkan dua atau lebih bidang ilmu. 
Peneliti menemukan peningkatan prestasi belajar tersebut terjadi karena peserta didik lebih merespon guru ketika guru memberikan pengaitan materi manfaat air dengan kehidupan nyata peserta didik. Selain itu saat guru memberikan tugas untuk mencari tahu perbedaan air tanah dan air permukaan, peserta didik melakukan praktikum terlebih dahulu dengan batu bata dan batu untuk mengamati perbedannya, setelah praktikum peserta didik berdiskusi mencari tahu perbedannya. Ketika proses diskusi peserta didik mendapatkan informasi baru dan membuat pengetahuan peserta didik bertambah.

Temuan yang peneliti temui yakni semakin meningkat sikap ilmiah peserta didik maka prestasi belajar peserta didik juga meningkat. Hal tersebut selaras dengan teori yang diungkapkan Harlen ada sembilan aspek sikap dari ilmiah yang dapat dikembangkan pada anak usia SD, meningkatnya sikap ilmiah selaras dengan meningkatkan pengembangan berfikir peserta didik yang dapat meningkatkan pemahaman peserta didik terhadap suatu materi, sehingga dapat meningkatkan hasil prestasi belajar peserta didik (Alawiyah et al., 2006).

Proses

pembelajaran

dilaksanakan sesuai dengan rencana pelaksanaan pembelajaran. Peneliti mengamati ketika penelitian berlangsung tampak peserta didik mengikuti pembelajaran dengan baik, evaluasi yang dikerjakan peserta didik mengalami peningkatan di setiap siklus dan pertemuan, temuan tersebut sesuai dengan pendapat (Slameto, 2010) yang menyatakan bahwa belajar ialah suatu proses usaha yang dilakukan seseorang untuk memperoleh suatu perubahan tingkah laku yang baru secara keseluruhan, sebagai hasil pengalamannya sendiri dalam interaksi dengan lingkungan.
Peningkatan prestasi belajar tersebut terjadi karena peserta didik mengalami penguasaan pengetahuan, saat peserta didik menguasai pengetahuan peserta didik mampu menjawab soal evaluasi. Hal tersebut sesuai dengan (Permanasari, 2016) yang mengatakan bahwa STEM mampu meningkatkan penguasaan pengetahuan, mengaplikasikan pengetahuan untuk memecahkan masalah, serta mendorong peserta didik untuk mencipta sesuatu yang baru.

\section{SIMPULAN}

Berdasarkan hasil penelitian yang dilakukan selama 2 siklus dalam rangka meningkatkan sikap ilmiah dan prestasi belajar peserta didik menggunakan model pembelajaran Science, Technology, Engineering, and Mathematics (STEM) pada Tema 8 di kelas V MI Muhammadiyah Kramat menunjukan hasil yang sesuai dengan yang harapan peneliti. Hasil penelitian yang ditemukan sebagai berikut: 1) Penggunaan model Science, Technology, Engineering, and Mathematics (STEM) pembelajaran Tema 8 mampu meningkatkan sikap ilmiah peserta didik di kelas V. Hasil rata-rata skor angket sikap ilmiah pada siklus I mendapatkan skor sebesar 3,7 yang termasuk kriteria baik lalu meningkat di siklus II mendapatkan skor sebesar 4,2 yang termasuk kriteria baik. Hasil rata-rata persentase observasi sikap ilmiah peserta didik pada siklus I mendapatkan persentase sebesar $50.35 \%$ yang termasuk kriteria kurang dan siklus II mendapatkan persentase sebesar $77.5 \%$ yang termasuk kriteria baik. 2) Penggunaan model Science, Technology, Engineering, and 
Mathematics (STEM) pembelajaran Tema 8 Lingkungan Sahabat Kita mampu meningkatkan prestasi belajar peserta didik di kelas V. Peningkatan prestasi belajar peserta didik mata pelajaran Bahasa Indonesia pada siklus I mendapat rata-rata nilai sebesar 55,05 dengan persentase ketuntasan belajar $35.3 \%$ dan siklus II mendapatkan rata-rata nilai 74,48 dengan persentase ketuntasan belajar 84.5\%. Peningkatan prestasi belajar peserta didik mata pelajaran IPA pada siklus I mendapat rata-rata nilai sebesar 55,1 dengan persentase ketuntasan belajar $40.3 \%$ dan siklus II mendapatkan rata-rata nilai 71,65 dengan persentase ketuntasan belajar $82 \%$. Pembelajaran dikatakan berhasil karena telah mencapai indikator keberhasilan ketuntasan belajar sekurang-kurangnya $80 \%$. Pemaparan hasil penelitian dan simpulan tersebut mungkin masih terdapat kekurangan. Peneliti menyadari bahwa selama penelitian berlangsung terdapat adanya keterbatasan, sehingga peneliti menyarankan apabila ingin meneliti hal yang serupa lebih dipertimbangkan kembali terkait waktu penelitian selama pembelajaran menggunakan model STEM, agar hasil yang di dapatkan lebih maksimal.

\section{DAFTAR RUJUKAN}

Alawiyah, I., Sopandi, W., \& Indonesia, U. P. (2006). Pembelajaran berbasis proyek untuk meningkatkan sikap ilmiah siswa sekolah dasar pada materi peristiwa alam. 84-97.

El-Deghaidy, H., \& Mansour, N. (2015). Science Teachers' Perceptions of STEM Education: Possibilities and Challenges.
International Journal of Learning and Teaching, 1(1), 51-54. https://doi.org/10.18178/ijlt.1.1.5 $1-54$

Hunaepi. (2016). Kajian Literatur tentang Pentingnya Sikap Ilmiah. Prosiding Seminar Nasional Pusat Kajian Pendidikan Sains Dan Matematika Tahun 2016, 548-550.

Jauhariyyah, F. R., Hadi Suwono, \& Ibrohim. (2017). Science, Technology, Engineering and Mathematics Project Based Learning ( STEM-PjBL ) pada Pembelajaran Sains. Pros. Seminar Pend. IPA Pascasarjana $U M, 2,432-436$.

Kurniaman, O., \& Noviana, E. (2019).

Penerapan Kurikulum 2013

Dalam Meningkatkan

Keterampilan, Sikap, Dan

Pengetahuan. Primary: Jurnal

Pendidikan Guru Sekolah Dasar, 6(2), 389.

https://doi.org/10.33578/jpfkip.v6 i2. 4520

Permanasari, A. (2016). STEM Education: Inovasi dalam Pembelajaran Sains. Prosiding Seminar Nasional Pendidikan Sains, 2016-2023. Retrieved from

https://media.neliti.com/media/pu blications/173124-ID-stemeducation-inovasi-dalampembelajara.pdf

Sardinah, Tursinawati, \& Noviyanti, A. (2012). Relevansi Sikap Ilmiah Siswa Dengan Konsep Hakikat Sains Dalam Pelaksanaan Percobaan Pada Pembelajaran Ipa Di Sdn Kota Banda Aceh. Jurnal Pendidikan Serambi Ilmu, 13, 70-80.

Slameto. (2010). Belajar \& Faktorfaktor yang Mempengaruhiya. Jakarta: Rineka Cipta.

Suryani, I. (2016). Pengembangan Instrumen Penilaian Sikap Ilmiah 
pada Pembelajaran dengan Model Latihan Penelitian di Sekolah Dasar. Jurnal Ilmiah Mahasiswa Pendidikan Guru Sekolah Dasar (PEDADIDAKTIKA), 3(2), 217227.

Trianto. (2012). Mendesain Model Pembelajaran Inovatif-Progresif. Jakarta: Kencana.

Utami, T. N., Jatmiko, A., \&
Suherman, S. (2018).

Pengembangan Modul

Matematika dengan Pendekatan

Science, Technology,

Engineering, And Mathematics (STEM) pada Materi Segiempat. Desimal: Jurnal Matematika, 1(2), 165.

https://doi.org/10.24042/djm.v1i2 .2388 